\title{
Immunosuppressive property of submandibular lymph nodes in patients with head and neck tumors: differential distribution of regulatory $T$ cells
}

\author{
Daiju Sakurai ${ }^{1 \dagger}$, Ryosuke Uchida ${ }^{1 \dagger}$, Fumie Ihara ${ }^{1,2}$, Naoki Kunii ${ }^{1}$, Takuya Nakagawa ${ }^{1}$, Hideaki Chazono ${ }^{1}$,
} Toyoyuki Hanazawa', Shinichiro Motohashi ${ }^{2}$ and Yoshitaka Okamoto ${ }^{1 *}$

\begin{abstract}
Objective: Different sensitizations and immune responses are thought to be induced in response to antigens at different mucosal sites between the oral floor and nose. The aim of this study was to investigate differences in the distributions of lymphocyte subsets in the submandibular (SM) and upper jugular (UJ) lymph nodes (LNs), which are supposed to be regional LNs of the oral floor and nasal mucosa, respectively. SMLNs and UJLNs were collected from patients with head and neck tumors who underwent surgical resection. The populations of T cells, Natural Killer (NK) cells, Natural Killer T (NKT) cells, regulatory T cells (Tregs) and dendritic cells (DCs) in LNs without metastasis were analyzed by flow cytometry. The high-affinity lgE receptor (FcERI) expression of LN cells were also evaluated.

Results: The proportions of $\mathrm{CD} 4^{+} \mathrm{CD} 25^{+}{ }^{+} \mathrm{Fxp}^{+}$Tregs, $\mathrm{CD} 4^{+} \mathrm{CD} 45 \mathrm{RA}{ }^{-}$Foxp $3^{\text {high }}$ effector Tregs and FceRla ${ }^{+} \mathrm{CD} 33^{+} \mathrm{CD} 11 \mathrm{C}^{+} \mathrm{DC}$ s were significantly larger in SMLNs compared with UJLNs, while those of CD $3^{+} \mathrm{T}$ cells, $\mathrm{CD}^{-} \mathrm{CD}_{56}{ }^{+} \mathrm{NK}$ cells, $\mathrm{CD} 3^{+} \mathrm{Va} 24^{+} \mathrm{V} \beta 11^{+} \mathrm{NKT}$ cells, and $\mathrm{CD} 123^{+} \mathrm{CD} 303^{+} \mathrm{DCs}$ did not show any significant differences between SMLNs and UJLNs. The differential distributions of $\mathrm{CD}^{+}{ }^{+} \mathrm{CD} 25^{+} \mathrm{Foxp} 3^{+}$Tregs were observed regardless of tumor region, LN metastasis and clinical staging. These data indicate that SMLNs may have immunosuppressive properties compared with UJLNs.
\end{abstract}

Keywords: Cervical lymph node, Dendritic cells, FcعRl, Head and neck tumor, Regulatory T cells, Submandibular lymph nodes, Upper jugular lymph nodes

\section{Introduction}

The nasal mucosa and oral mucosa are located at the entrance of the respiratory tract and gastrointestinal tract, respectively, and are constantly exposed to various antigens. However, different sensitizations and immune responses are induced in response to antigens at these different mucosal sites. When the nasal mucosa is exposed to allergens, specific IgE production is evoked,

*Correspondence: yokamoto@faculty.chiba-u.jp

†Daiju Sakurai and Ryosuke Uchida contributed equally to this work

1 Department of Otorhinolaryngology, Head and Neck Surgery,

Graduate School of Medicine, Chiba University, 1-8-1 Inohana, Chuo-ku,

Chiba 260-8670, Japan

Full list of author information is available at the end of the article and following repeated exposure to the allergen, typical nasal symptoms of allergic rhinitis (AR) are induced. In contrast, the oral cavity is exposed to various foreign substances, such as foods, bacteria, and viruses, but excessive immune responses, such as oral allergy syndrome, are normally restrained. Sublingual immunotherapy (SLIT), in which an allergen is applied to the oral floor in patients with various allergic diseases, attenuates allergic reactions $[1,2]$. Conversely, the administration of a viral vaccine, such as the influenza vaccine, to the nasal mucosa enhances immune responses against the virus $[3,4]$. It is therefore known that there are differential immune responses between the nasal mucosa and oral mucosa following antigen exposure. 
Dendritic cells (DCs) capture antigens exposed to the mucosa and migrate to regional lymph nodes (LNs), where they present the antigen to lymphocytes [5]. Differential characteristics of DCs between the oral and nasal mucosa have been previously reported [6]. The different immunocompetent cells at various mucosal sites are expected to induce different immune responses.

It has also been reported that cultured DCs administered to the nasal submucosa quickly migrate to upper jugular lymph nodes (UJLNs), while those administered to the oral floor mucosa migrate to submandibular lymph nodes (SMLNs) $[8,9]$. A significant increase in the number of peripheral Natural Killer T cells (NKT cells) has been observed following the nasal submucosal administration of DCs pulsed with $\alpha$-galactosylceramide $(\alpha G a l C e r)$, a specific ligand for invariant NKT cells, while this response was not observed following administration in the oral floor mucosa [8]. These results suggest that the differential immunological responses observed between the nasal and oral mucosa depend upon differences in each type of mucosa, including sites involving DCs as well as differences in draining LNs.

In this study, we investigated the differential distribution of lymphocyte subsets between SMLNs and UJLNs collected from the surgical specimens of patients with head and neck tumors.

\section{Main text \\ Materials and methods \\ Patient samples}

30 patients between 36 and 84 years old with head and neck tumors were enrolled in this study (Additional file 1: Table S1). All patients underwent surgery in the Department of Otorhinolaryngology and Head and Neck Surgery, Chiba University Hospital. We sorted the dissected LNs into different LN regions (SMLNs and UJLNs) immediately after the operation. A representative LN ranging from 7 to $10 \mathrm{~mm}$ in diameter from SMLN and UJLN regions of each patient was collected, and split samples of approximately $5 \mathrm{~mm}^{3}$ from these lymph nodes were used for analysis. Approximately $1 \times 10^{7}$ cells were collected from the segments, and other segments were submitted for pathological diagnosis. LNs without metastasis were confirmed by pathological examination. The study was approved by the Ethics Committee of Chiba University. Written informed consent was obtained from each patient prior to participation in the study.

\section{Lymph node mononuclear cells (LNMCs)}

The collected LNs were placed in complete RPMI1640 medium, and then homogenized to generate LNMCs, which were filtered through a nylon mesh and washed twice in complete RPMI1640 medium.

\section{Flow cytometry}

LNMCs were stained with the following anti-human antibodies: anti-CD3 APC, anti-CD56 PE-Cy7, antiCD4 PacificBlue, anti-CD25 PE, anti-CD45RA FITC, anti-CD33 FITC (BD Bioscience, Franklin Lakes, NJ, USA), anti-V $\alpha 24$ FITC, anti-V $\beta 11$ (Beckman Coulter, Brea, CA, USA), anti-CD123 eFluor450, anti-FceRI $\alpha$ PE (Affymetrix, Santa Clara, CA, USA), and anti-CD303 FITC (Miltenyi Biotec, Bergisch Gladbach, Germany) for surface staining. Anti-Foxp3-eflour660 (eBioscience) was used for intracellular staining. The Fixation/Permeabilization Diluent and Concentrate, and Permeabilization Buffer (all from Affymetrix) were used to fix and permeabilized the cells according to the manufacturer's instructions. Cellular phenotypes were evaluated using the FACSCanto II system (BD Biosciences). Data were analyzed using FlowJo software (Tree Star Inc., Ashland, OR, USA).

\section{Statistical analysis}

Statistical analyses were performed using the paired and unpaired $t$ test. A value of $\mathrm{p}<0.05$ was considered statistically significant.

\section{Results}

Differential distribution of $\mathrm{CD} 4^{+} \mathrm{CD} 25^{+} \mathrm{Foxp}^{+}$regulatory $T$ cells (Tregs) between SMLNs and UJLNs

To investigate the characteristics of LNMCs extracted from SMLNs and UJLNs, the proportions of $\mathrm{CD}^{+} \mathrm{T}$ cells, $\mathrm{CD}^{-} \mathrm{CD}^{-} 6^{+} \mathrm{NK}$ cells, $\mathrm{CD} 3^{+} \mathrm{V} \alpha 24^{+} \mathrm{V} \beta 11^{+} \mathrm{NKT}$ cells and $\mathrm{CD} 4^{+} \mathrm{CD} 25^{+}$Foxp $3^{+}$Tregs in the LNMCs were analyzed. The populations of $\mathrm{CD}^{+}$cells, $\mathrm{CD}^{-} \mathrm{CD}^{-} 6^{+}$ cells and $\mathrm{CD}^{+} \mathrm{V} \alpha 24^{+} \mathrm{V} \beta 11^{+}$cells in SMLNs and UJLNs did not show any significant differences (Fig. 1a-c). The proportion of $\mathrm{CD} 4^{+} \mathrm{CD} 25^{+} \mathrm{Foxp}^{+}$cells in SMLNs was significantly larger than in UJLNs $(\mathrm{p}<0.01$; Fig. 1d). The subsets of $\mathrm{CD} 44^{+} \mathrm{Foxp}^{+}$Tregs were analyzed based on CD45RA and Foxp3 expression. The proportion of CD45RA ${ }^{-}$Foxp $3^{\text {high }}$ cells among $\mathrm{CD}^{+}{ }^{+}$Foxp $^{+}$cells in SMLNs was significantly larger than in UJLNs $(p<0.01$; Fig. 1e). Conversely, the proportion of CD45RA ${ }^{+}$Foxp $3^{\text {low }}$ cells among the $\mathrm{CD} 4^{+}{ }^{\mathrm{Foxp}} 3^{+}$cells in SMLNs and UJLNs were not significantly different (Fig. 1f). The proportion of $\mathrm{CD} 4^{+} \mathrm{T}$ cells among the LNMCs were not significantly different (Fig. 1g).

\section{Increased $C D 4^{+} \mathrm{CD} 25^{+} \mathrm{Foxp}^{+}{ }^{+}$Tregs in SMLNs independent of clinical features}

The proportions of $\mathrm{CD} 4{ }^{+} \mathrm{CD} 25^{+} \mathrm{Foxp} 3^{+}$cells among LNMCs from SMLNs were significantly larger than those of UJLNs collected from patients with both oral cancer $(\mathrm{p}<0.01$; Fig. 2a) and cancer at other sites $(\mathrm{p}<0.01$; 

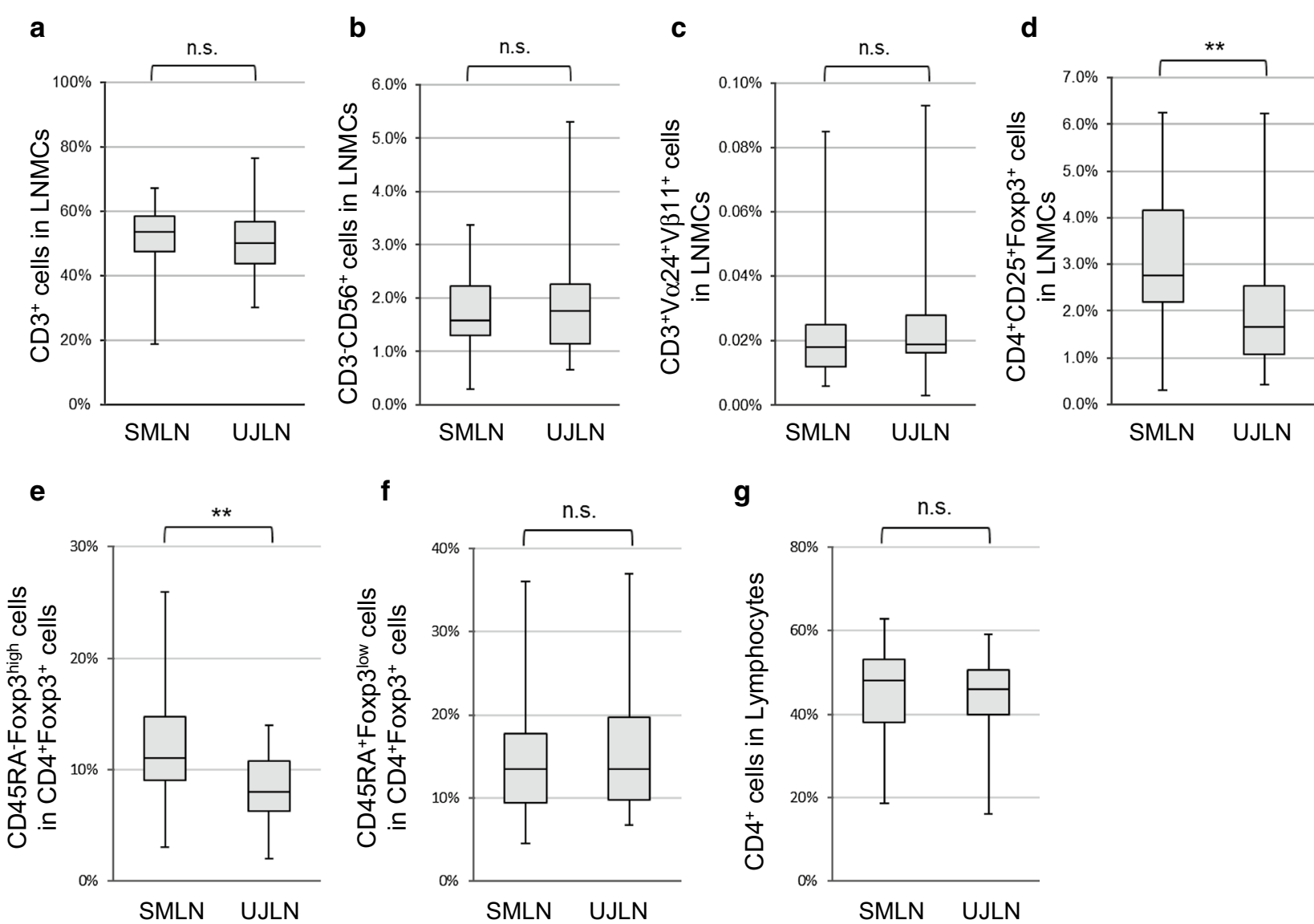

Fig. 1 The distributions of lymphocyte subsets in SMLNs and UJLNs. The proportions of CD3 ${ }^{+}$cells $(\mathbf{a}), \mathrm{CD}^{-} \mathrm{CD} 56^{+}$cells $(\mathbf{b}), \mathrm{CD}^{+} \mathrm{Va2} 4^{+} \mathrm{V} \beta 11^{+}$

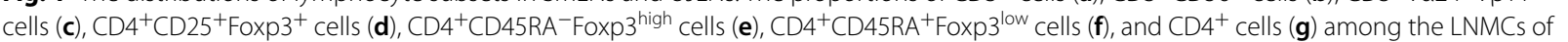
SMLNs and UJLNs are shown $(n=30)$. The data are shown as boxplots. The central rectangle spans indicate the first quartile to the third quartile. The segment inside the rectangle shows the median and whiskers above and below the box show minimum and maximum values, respectively. The $p$ values were obtained by the unpaired t-test. ${ }^{* *} p<0.01$; n.s. not significant

Fig. 2b), in both early- ( $<<0.05$; Fig. $2 \mathrm{c})$ and advancedstage $(\mathrm{p}<0.01$; Fig. $2 \mathrm{~d})$ cases, and in patients with or without LN metastasis $(\mathrm{p}<0.01$ and $\mathrm{p}<0.01$, respectively; Fig. 2e, f).

\section{Increased proportion of $\mathrm{FcERI}^{+} \mathrm{CD} 33^{+} \mathrm{CD} 11 \mathrm{c}^{+}$cells in SMLNs}

The proportions of both $\mathrm{CD} 123^{+} \mathrm{CD} 303^{+}$and $\mathrm{CD}_{3}{ }^{+} \mathrm{CD} 11 \mathrm{c}^{+}$cells in the LNMCs did not show any significant differences between SMLNs and UJLNs (Fig. 3a, b). However, the proportion of FcERIa ${ }^{+} \mathrm{CD} 33^{+} \mathrm{CD} 11 \mathrm{c}^{+}$ cells in LNMCs was significantly larger in SMLNs than UJLNs ( $\mathrm{p}<0.05$; Fig. 3c).

\section{Discussion}

In this study, the immunological differences of LNMCs between SMLNs and UJLNs were investigated, and our data suggested that SMLNs had more immunosuppressive properties than UJLNs. We first examined the proportion of lymphocytes between SMLNs and UJLNs, but no significant differences in $\mathrm{CD}^{+}{ }^{+} \mathrm{T}$ cells, $\mathrm{CD}^{-} \mathrm{CD} 56^{+}$ $\mathrm{NK}$ cells or $\mathrm{CD}^{+} \mathrm{V} \alpha 24^{+} \mathrm{V} \beta 11^{+}$NKT cells were observed. However, significantly higher proportions of $\mathrm{CD} 4{ }^{+} \mathrm{CD} 25^{+} \mathrm{Foxp}^{+}$Tregs were detected in SMLNs than in UJLNs. Recently, CD4 ${ }^{+}$Foxp $3^{+}$Tregs were reported to be further subdivided into functionally distinct subpopulations based on CD45RA and Foxp3 expression [10]. CD45RA ${ }^{-}$Foxp $3^{\text {high }}$ Tregs expressed more CTLA-4 and IL-2 (CD25) receptor on their cell surfaces and had potent immunosuppressive activities for $\mathrm{T}$ cells, and were thus called effector Tregs $[11,12]$. In this study, a significantly higher proportion of $\mathrm{CD} 4{ }^{+} \mathrm{CD} 45 \mathrm{RA}^{-}$Foxp $3^{\text {high }}$ effector Tregs was found in SMLNs compared with UJLNs.

The LNMCs from the SMLNs and UJLNs used in this study were collected from surgically resected specimens from patients with head and neck tumors. The frequency of Tregs in the peripheral blood has been reported to be elevated in patients with cancer, 

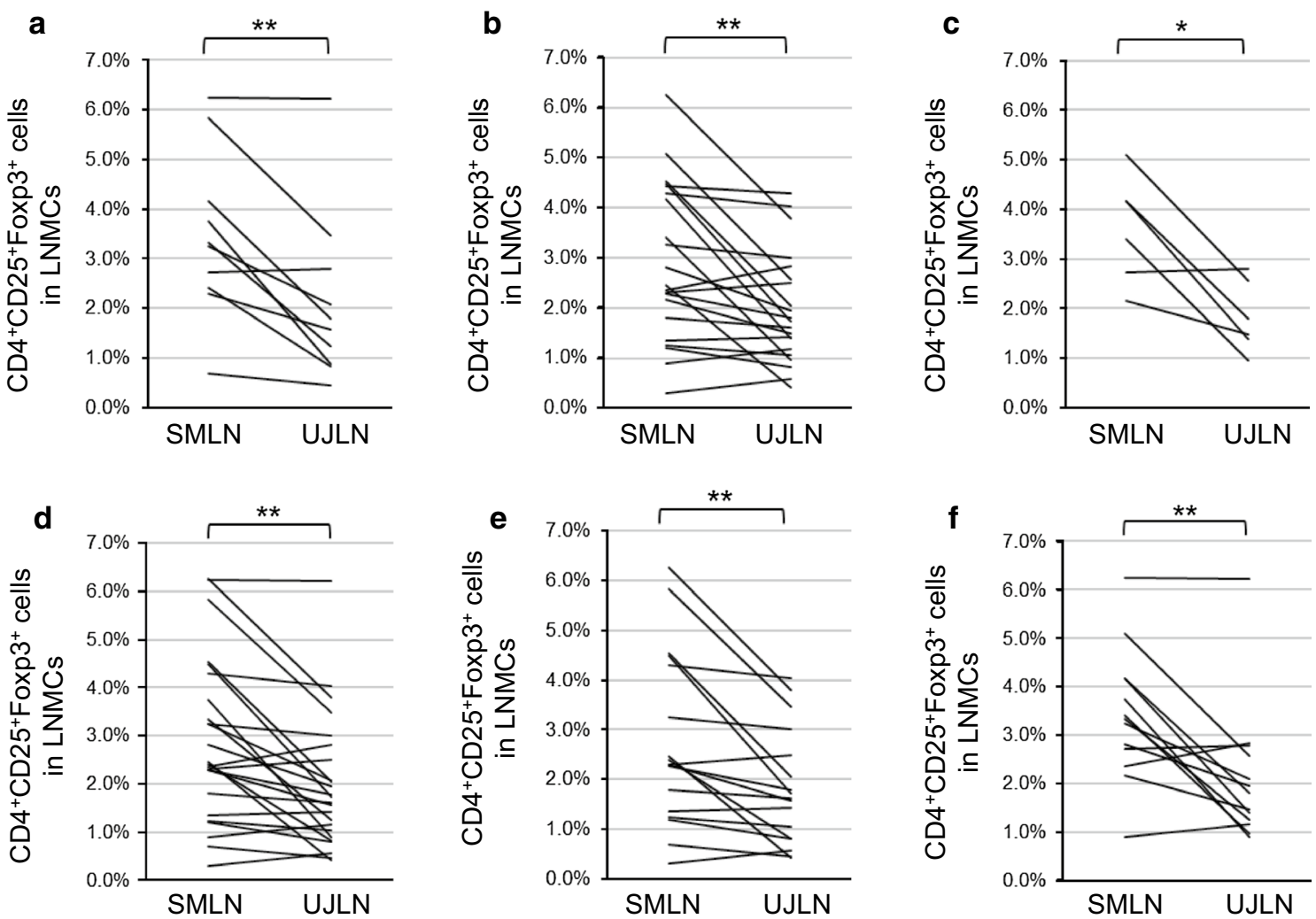

Fig. 2 The proportion of $C D 4^{+} \mathrm{CD} 25^{+}{ }^{+} \operatorname{Fxp}^{+}$Tregs among LNMCs from SMLNs and UJLNs based on clinical features. The percentage of $\mathrm{CD}^{+}{ }^{+} \mathrm{CD} 25^{+} \mathrm{Foxp}^{+}$cells among LNMCs from SMLNs and UJLNs are shown $(\mathbf{a}-\mathbf{f})$. The tongue and oral cavity tumor patients are shown in $(\mathbf{a})$ $(n=10)$, and those with tumors in other regions are shown in $(\mathbf{b})(n=20)$. An early-stage group, which included patients with stage I, II and benign tumors $(n=6)(\mathbf{c})$, and an advanced-stage group, which included stage III, IV and recurrent tumors $(n=24)(\mathbf{d})$. The results of an analysis of patients with LN metastasis are shown in $(\mathbf{e})(n=17)$, while those of patients without LN metastasis are shown in $(\mathbf{f})(n=13)$. The $p$-values were obtained by the paired t-test. ${ }^{*} p<0.05 ;{ }^{* *} p<0.01$; n.s. not significant
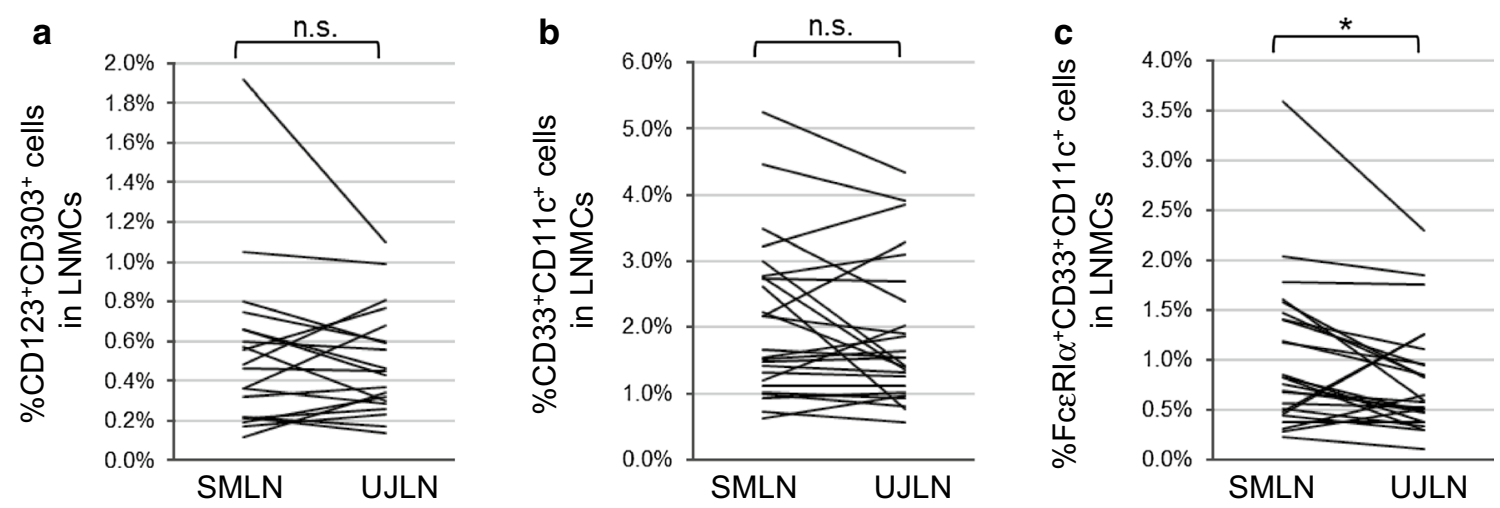

Fig. 3 The distribution of $\mathrm{CD} 123^{+} \mathrm{CD}_{303}{ }^{+}$cells and $\mathrm{CD} 11 \mathrm{C}^{+} \mathrm{CD} 33^{+}$cells among $\mathrm{LNMCs}$ from SMLNs and UJLNs. The proportions of $\mathrm{CD} 123^{+} \mathrm{CD} 303^{+}$ cells (a), CD11 $c^{+} \mathrm{CD} 33^{+}$cells $(\mathbf{b})$ and FcERla ${ }^{+} \mathrm{CD} 11 \mathrm{c}^{+} \mathrm{CD} 33^{+}$cells (c) among LNMCs from SMLNs and UJLNs are shown. The p-values were obtained by the paired t-test. ${ }^{*} p<0.05 ;$ n.s. not significant

including those with head and neck cancer [13, 14]. These results might reflect the increased regulatory $\mathrm{T}$ cells in LNs with metastasis and primary tumors in cancer patients which were associated with clinical stage and the presence of lymph node metastasis [13]. Therefore, we examined the influence of tumor-related 
factors such as the primary tumor region, the presence of cervical LN metastasis and clinical stage on differences in the Treg proportions between SMLNs and UJLNs. However, significant differences in the proportion of $\mathrm{CD} 4{ }^{+} \mathrm{CD} 25^{+}$Foxp $3^{+}$Tregs between SMLNs and UJLNs remained, regardless of the clinical features examined. This suggested that increased Tregs were characteristic of SMLNs compared with UJLNs.

In a previous study, DCs administered to the nasal mucosa migrated to UJLNs, while those administered to the oral floor mucosa migrated to SMLNs $[8,9]$. Additionally, a significant increase in the number of peripheral NKT cells has been observed after administering DCs pulsed with the NKT cell ligand $\alpha$ GalCer into the nasal mucosa. However, these activities were not detected after administering DCs into the oral floor mucosa [8]. Although the mechanisms remain unknown, it has been suggested that the NKT cell activation by DCs that migrated from the oral floor mucosa might be inhibited by the increased Tregs in SMLNs, which are the draining LNs of the oral floor mucosa.

The induction and expansion of Tregs have been shown to be controlled by DCs $[15,16]$. Human DCs have two major subtypes, conventional DCs (cDCs) and plasmacytoid DCs (pDCs) [17]. cDCs have can stimulate $\mathrm{T}$ cells, evoking Th1- or Th2-responses, depending on the inflammatory environment [18-20]. pDCs produce type I interferon when there is an infection [18], and it has been suggested that they induce $\mathrm{T}$ cell tolerance $[18,20]$. In this study, although we analyzed $\mathrm{CD} 123^{+} \mathrm{CD} 303^{+}$pDCs and $\mathrm{CD} 33^{+} \mathrm{CD} 11 \mathrm{c}^{+}$cells which included $\mathrm{CDC}$, macrophage and monocyte populations, no differences were found between SMLNs and UJLNs.

The oral mucosa is known to have a lot of DCs that express FceRI [7, 21], and allergens can be taken up by IgE molecules bound to the FceRI expressed on oral DCs [22]. In this study, a larger proportion of FceRIexpressing $\mathrm{CD}_{3}{ }^{+} \mathrm{CD} 11 \mathrm{c}^{+}$cells was observed in submandibular LNMCs compared with upper jugular LNMCs. These FceRI-expressing cDCs might migrate to the SMLNs from the oral mucosa, where they induce Treg and immune tolerance to various commonly-exposed antigens or to allergens administrated by sublingual immunotherapy $[7,23]$.

\section{Conclusion}

In this study, we identified a differential distribution of lymphocyte subsets between SMLNs and UJLNs. The proportions of $\mathrm{CD} 4{ }^{+} \mathrm{CD} 25^{+} \mathrm{Foxp} 3^{+}$Tregs, CD $4{ }^{+}$CD 45 RA $^{-}$Foxp $3{ }^{\text {high }}$ effector Tregs and FceRIexpressing $\mathrm{CD}^{-} 3^{+} \mathrm{CD} 11 \mathrm{c}^{+}$cells in SMLNs were larger than those in UJLNs. SMLNs may have more potent immunosuppressive properties than UJLNs.

\section{Limitations}

In this study, we examined the difference in the distribution of immune cells in two LN regions. However, a limitation of this study is that the samples were restricted to tumor patients who underwent surgery because it is unethical to collect LNs from healthy subjects. It is possible that the distribution of immune cells in LNs differed between patients with head and neck tumors and healthy subjects, but it is difficult to compare immune cell profiles between these groups. Additionally, the detailed interactions between Tregs and FceRI-expressing $\mathrm{CD} 33^{+} \mathrm{CD} 11 \mathrm{c}^{+}$cells, and their suppressive functions and effects on immune cells in lymph nodes needs further investigation.

\section{Additional file}

Additional file 1: Table S1. Clinical characteristics of the head and neck tumor patients. Clinical characteristics of the head and neck tumor patients enrolled in this study.

\section{Abbreviations}

aGalCer: a-galactosylceramide; AR: allergic rhinitis; CDC: conventional dendritic cell; DC: dendritic cell; LNMC: lymph node mononuclear cell; NK cell: Natural Killer cell; NKT cell: Natural Killer T cell; pDC: plasmacytoid dendritic cell; SLIT: sublingual immunotherapy; SMLN: submandibular lymph node; Treg: regulatory T cell; FcERI: the high-affinity IgE receptor; UJLN: upper jugular lymph node.

\section{Authors' contributions}

DS and RU contributed equally to this work. DS, RU, SM and YO designed and developed the protocol for the study. Fl, NK, TN, HC and TH contributed to develop the protocol. DS, RU, FI, NK, TN, HC and TH collected the samples and conducted the acquisition of data. DS, RU FI, NK, TN, HC and TH performed the analysis of results. DS and RU wrote the manuscript. SM, TH and YO supervised the study and reviewed the manuscript. All authors read and approved the final manuscript.

\section{Author details \\ 1 Department of Otorhinolaryngology, Head and Neck Surgery, Graduate School of Medicine, Chiba University, 1-8-1 Inohana, Chuo-ku, Chiba 260-8670, Japan. ${ }^{2}$ Department of Medical Immunology, Graduate School of Medicine, Chiba University, 1-8-1 Inohana, Chuo-ku, Chiba 260-8670, Japan.}

\section{Acknowledgements}

We thank all the patients who participated in this study. We also thank James P. Mahaffey, Ph.D., from Edanz Group (http://www.edanzediting.com/ac) for editing a draft of this manuscript.

\section{Competing interests}

The authors declare that they have no competing interests.

Availability of data and materials

All data generated or analyzed during this study are included in this published article.

Consent for publication

Not applicable. 


\section{Ethics approval and consent to participate}

The study was approved by the Ethics Committee of Chiba University. Written informed consent was obtained from each patient prior to participation in the study.

\section{Funding}

This work was supported by the Japan Society for the Promotion of Science KAKENHI under Grant (Number 15K107999).

\section{Publisher's Note}

Springer Nature remains neutral with regard to jurisdictional claims in published maps and institutional affiliations.

Received: 1 June 2018 Accepted: 10 July 2018

Published online: 16 July 2018

\section{References}

1. Wilson DR, Lima MT, Durham SR. Sublingual immunotherapy for allergic rhinitis: systematic review and meta-analysis. Allergy. 2005;60:4-12.

2. Gidaro GB, Marcucci F, Sensi L, Incorvaia C, Frati F, Ciprandi G. The safety of sublingual-swallow immunotherapy: an analysis of published studies. Clin Exp Allegy. 2005:35:565-71.

3. Rose M, Zielen S, Baumann U. Mucosal immunity and nasal influenza vaccination. Expert Rev Vaccines. 2012;11:595-607.

4. Lycke N. Recent progress in mucosal vaccine development: potential and limitations. Nat Rev Immunol. 2012;12:592-605.

5. Wu RQ, Zhang DF, Tu E, Chen QM, Chen W. The mucosal immune system in the oral cavity - an orchestra of T cell diversity. Int J Oral Sci. 2014;6:125-32.

6. Allam JP, Niederhagen B, Bücheler M, Appel T, Betten H, Bieber T, Bergé S, Novak N. Comparative analysis of nasal and oral mucosa dendritic cells. Allergy. 2006;61:166-72

7. Allam JP, Novak N, Fuchs C, Asen S, Berge S, Appel T, Geiger E, Kochan JP, Bieber T. Characterization of dendritic cells from human oral mucosa: a new Langerhans' cell type with high constitutive FcepsilonRI expression. J Allergy Clin Immunol. 2003;112:141-8.

8. Kurosaki M, Horiguchi S, Yamasaki K, Uchida Y, Motohashi S, Nakayama T, Sugimoto A, Okamoto Y. Migration and immunological reaction after the administration of aGalCer-pulsed antigen-presenting cells into the submucosa of patients with head and neck cancer. Cancer Immunol Immunother. 2011;60:207-15

9. Horiguchi S, Matsuoka T, Okamoto Y, Sakurai D, Kobayashi K, Chazono H, Hanazawa T, Tanaka Y. Migration of tumor antigen-pulsed dendritic cells after mucosal administration in the human upper respiratory tract. J Clin Immunol. 2007:27:598-604.
10. Miyara M, Yoshioka Y, Kitoh A, Shima T, Wing K, Niwa A, Parizot C, Taflin C, Heike T, Valeyre D, Mathian A, Nakahata T, Yamaguchi T, Nomura T, Ono M, Amoura Z, Gorochov G, Sakaguchi S. Functional delineation and differentiation dynamics of human CD4+ T cells expressing the FoxP3 transcription factor. Immunity. 2009;30:899-911.

11. Ihara F, Sakurai D, Horinaka A, Makita Y, Fujikawa A, Sakurai T, Yamasaki K, Kunii N, Motohashi S, Nakayama T, Okamoto Y. CD45RA-Foxp3high regulatory $T$ cells have a negative impact on the clinical outcome of head and neck squamous cell carcinoma. Cancer Immunol Immunother. 2017;66:1275-85.

12. Tanaka A, Sakaguchi S. Regulatory T cells in cancer immunotherapy. Cell Res. 2017:27:109-18.

13. Chen B, Zhang D, Zhou J, Li Q, Zhou L, Li SM, Zhu L, Chou KY, Zhou L, Tao L, Lu LM. High CCR6/CCR7 expression and Foxp3 ${ }^{+}$Treg cell number are positively related to the progression of laryngeal squamous cell carcinoma. Oncol Rep. 2013:30:1380-90.

14. Azuma T, Takahashi T, Kunisato A, Kitamura T, Hirai H. Human CD4+CD25+ regulatory T cells suppress NKT cell functions. Cancer Res. 2003;63:4516-20.

15. Yamazaki S, Inaba K, Tarbell KV, Steinman RM. Dendritic cells expand antigen-specific Foxp3+ CD25 + CD4+ regulatory T cells including suppressors of alloreactivity. Immunol Rev. 2006;212:314-29.

16. Yamazaki S, Steinman RM. Dendritic cells as controllers of antigen-specific Foxp3+ regulatory T cells. J Dermatol Sci. 2009;54:69-75.

17. Sato K, Fujita S. Dendritic cells-nature and classification. Allergol Int. 2007;56:183-91.

18. Wang YH, Ito T, Wang YH, Homey B, Watanabe N, Martin R, Barnes CJ, Mclntyre BW, Gilliet M, Kumar R, Yao Z, Liu YJ. Maintenance and polarization of human $\mathrm{TH} 2$ central memory T cells by thymic stromal lymphopoietinactivated dendritic cells. Immunity. 2006;24:827-38.

19. Ito T, Amakawa R, Inaba M, Hori T, Ota M, Nakamura K, Takebayashi M, Miyaji M, Yoshimura T, Inaba K, Fukuhara S. Plasmacytoid dendritic cells regulate Th cell responses through OX40 ligand and type I IFNs. J Immunol. 2004;172:4253-9.

20. Ito $T$, Yang M, Wang YH, Lande R, Gregorio J, Perng OA, Qin XF, Liu YJ, Gilliet M. Plasmacytoid dendritic cells prime IL-10-producing T regulatory cells by inducible costimulator ligand. J Exp Med. 2007;204:105-15.

21. Yamazaki S, Maruyama A, Okada K, Matsumoto M, Morita A, Seya T. Dendritic cells from oral cavity induce Foxp3+ regulatory t cells upon antigen stimulation. PLOS ONE. 2012:7:e51665.

22. Novak N. New insights into the mechanism and management of allergic diseases: atopic dermatitis. Allergy. 2009:64:265-75.

23. Moingeon P, Batard T, Fadel R, Frati F, Sieber J, Van Overtvelt L. Immune mechanisms of allergen-specific sublingual immunotherapy. Allergy. 2006:61:151-65.
Ready to submit your research? Choose BMC and benefit from:

- fast, convenient online submission

- thorough peer review by experienced researchers in your field

- rapid publication on acceptance

- support for research data, including large and complex data types

- gold Open Access which fosters wider collaboration and increased citations

- maximum visibility for your research: over 100M website views per year

At BMC, research is always in progress.

Learn more biomedcentral.com/submissions 